University of Nebraska - Lincoln

DigitalCommons@University of Nebraska - Lincoln

Faculty Publications, UNL Libraries

Libraries at University of Nebraska-Lincoln

2011

\title{
Presidential Vetoes and American Indian Affairs, 1789-2000
}

\author{
Charles D. Bernholz \\ University of Nebraska-Lincoln, cbernholz2@unl.edu \\ Laura Weakly \\ University of Nebraska-Lincoln, Iweakly2@unl.edu \\ Brian Pytlik Zillig \\ University of Nebraska-Lincoln, bzillig1@unl.edu \\ Karin Dalziel \\ University of Nebraska-Lincoln, kdalziel2@unl.edu
}

Follow this and additional works at: https://digitalcommons.unl.edu/libraryscience

Part of the Library and Information Science Commons

Bernholz, Charles D.; Weakly, Laura; Pytlik Zillig, Brian; and Dalziel, Karin, "Presidential Vetoes and American Indian Affairs, 1789-2000" (2011). Faculty Publications, UNL Libraries. 236.

https://digitalcommons.unl.edu/libraryscience/236

This Article is brought to you for free and open access by the Libraries at University of Nebraska-Lincoln at DigitalCommons@University of Nebraska - Lincoln. It has been accepted for inclusion in Faculty Publications, UNL Libraries by an authorized administrator of DigitalCommons@University of Nebraska - Lincoln. 
Published in Library Collections, Acquisitions, E Technical Services 35 (2011), pp. 61-63;

doi: 10.1016/j.lcats.2010.12.001 Copyright @ 2011 Elsevier Ltd. Used by permission.

Published online February 24, 2011.

\title{
Presidential Vetoes and American Indian Affairs, 1789-2000
}

\author{
Charles D. Bernholz, ${ }^{1}$ Laura K. Weakly, ${ }^{2}$ Brian L. Pytlik Zillig, ${ }^{2}$ and Karin Dalziel ${ }^{2}$ \\ 1. Love Memorial Library, University of Nebraska-Lincoln, Lincoln, NE 68588, USA \\ 2. Electronic Text Center, Love Memorial Library, University of Nebraska-Lincoln, \\ Lincoln, NE 68588, USA; fax 402 472-5181, email etcenter@unl.edu \\ Corresponding author - C. D. Bernholz, fax 402 472-5181, email cbernholz2@unl.edu
}

\begin{abstract}
Between the years 1789 and 2000, nineteen Presidents of the United States vetoed 114 bills or resolutions concerning matters related to Indian affairs. These executive actions are collected in a new digital resource, and are presented with their supporting Congressional documents. A brief history of Presidential veto power and activities is included.
\end{abstract}

Keywords: Presidential veto, American Indians, Indian Affairs

\section{Introduction}

Clause 2 of section 7 in Article I of the U.S. Constitution affirms:

Every Bill which shall have passed the House of Representatives and the Senate, shall, before it become a Law, be presented to the President of the United States; If he approve he shall sign it, but if not he shall return it, with his Objections to that House in which it shall have originated, who shall enter the Objections at large on their Journal, and proceed to reconsider it. If after such Reconsideration two thirds of that House shall agree to pass the Bill, it shall be sent, together with the Objections, to the other House, by which it shall likewise be reconsidered, and if approved by two thirds of that House, it shall become a Law. But in all such Cases the Votes of both Houses shall be determined by Yeas and Nays, and the Names of the Persons voting for and against the Bill shall be entered on the Journal of each House respectively. If any Bill shall not be returned by the President within ten Days (Sundays excepted) after it shall have been presented to him, the Same shall be a Law, in like Manner as if he had signed it, unless the Congress by their Adjournment prevent its Return, in which Case it shall not be a Law.

(The Constitution of the United States: Analysis and Interpretation, 2004, p. 143; emphasis added)

The italicized portion refers to the condition under which a so-called pocket veto-as opposed to the regular form - may take effect (see Pope, 1986 for more on this specific tool).

George Washington was a cautious President and believed that this veto power required special attention, since the stability of influence between the legislature and the executive might be resolved only through the rules applicable to the deployment of this authority. Over time, the two worlds of constitutionality and expediency have offered the substrates upon which United States Presidents might exercise this leverage, where the former consideration was especially relevant to early administrations, while the latter concern developed during later ones (Mason, 1891, pp. 129-130). Washington, during four Congresses, vetoed two House resolutions, one pivoting on constitutional grounds and the other on expediency; the House failed to override either one of these. In this process, Washington thus relied upon both the directions dictated by the Constitution, and a careful consideration of policy judgments. 


\section{The Veto in America}

Edward Campbell Mason compiled a history of presidential vetoes between the years 1789 and 1889, and his editor-Albert Bushnell Hart-declared that this privilege was the most important of the institutions connecting the national executive with the legislature (Mason, 1891, p. 3). Hart noted, however, that there had been a previous Senate effort to collate vetoes (Veto Messages of the Presidents ..., 1886), but that this assortment was supplemented by Mason to create a suite of more than 430 separate transactions through the end of the first Cleveland administration in 1889. In his effort, Mason identified only seven Presidents during more than two centuries of American politics who chose not to affect a veto: John Adams, Thomas Jefferson, John Quincy Adams, Martin Van Buren, William Henry Harrison, Zachary Taylor, and James Garfield (Mason, 1891, pp. 126127). A more recent compilation Presidential Vetoes, 1789-1988 (1992) revealed one veto performed by Van Buren (p. 13), and added Millard Fillmore to the list of Presidents who did not convey vetoes (p. 21).

A more recent compilation of this executive behavior has shown far more vetoes than even those enumerated by Mason: his 433 decisions were overshadowed by the 621 actions located by the Office of the Secretary of the Senate for the same interval of Presidential service (Presidential Vetoes, 1789-1988, p. ix). The eighty-five page Index of this volume divulges a vast array of situations under which the Presidents issued those vetoes. An additional manual was furnished in 1992 (Presidential Vetoes, 1989-1991) and then again in 1994 (Presidential

Vetoes, 1989-1994), in 1997 (Presidential Vetoes, 1989-1996), and in 2001 (Presidential Vetoes, 1989-2000). Taken together, these materials reveal forty-one men who served as President forty-two times between the years of 1789 and 2000, with a cumulative veto count for all federal issues stretching beyond 2500 by the end of William J. Clinton's years in office. Two Chief Executives were particularly active with this means: Grover Cleveland (as the sole two-time President) initiated 584 vetoes, divided between 346 regular and 238 pocket cases, and Franklin D. Roosevelt imposed 635, consisting of 372 regular and 263 pocket instances. Together, these two caused $47 \%$ of all federal vetoes through the year 2000 (Presidential Vetoes, 1989-2000, p. ix).

WTHOUT APPROVAI SENATE BILI 4862, ENTITLED "AN $\triangle$ CT FOR THE RELTEF OF CERTAIN PERSONS HAVING SUPPLIED LABOR AND MATERIALS FOR THE PROSECUTION OF THE WORK OF CONSTRUCTING THE CORBETT TUNNEL OF THE SHOSHONE IRRIGATION PROJECT," TOGETHER WITH THE REPORT OF THE SECRE. TARY OF THE INTERIOR IN RELATION THERETO.

JuLY 18, 1912.--Read; ordered to lic on the table and to be printed.

To the Senate:

For the reasons stated in the letter of July 12 of the Secretary of the Interior, which accompanies this message, I roturn without approval Senate bill 4862 , entitled " $\mathrm{An}$ act for the relief of certain persons having supplied labor and materials for the prosecution of the work of constructing the Corbett Tunnel of the Shoshone irrigntion project."

I do this because I think this legislation is of retroactive character and imposes on certain of the reclamation settlers an additional burden over and above the contract price of the work done, increasing that price by a double payment of part of what was due under the contract from the reclamation fund to the principal contractors. At the time when the work was berun and continued there was no law which relieved the subcontractor or the material man from the necessity of looking after the collection of what the contractor owed him or which imposed on the Government or the reclamation authorities the duty of seeing to it that the money pide the duty of seeing to it that the money paid under the principal contract was used by the principal contractor to pay his subcontractors or material men. To require that this additional amount should now be included in the assessment upon the lands is by law to increase contract burden by a change of the character of the liability after it has been assumed and fixed. This is rotroactive and is legislation in its nature unjust to the reclamation settlers.

Tue Whrte House, July 18, 1912.

WM. H. TAFT.
Figure 1. The complete text of William Howard Taft's 1912 Veto Message Relating to the Corbett Tunnel of the Shoshone Irrigation Project. 


\section{Vetoes and the Realm of Indian Affairs}

Indian affairs have always been an important component of any President's responsibilities: during the period of treaty making with American Indians, each President between George Washington and Ulysses S. Grant except for William H. Harrison and Zachary Taylor proclaimed at least one such contract (Bernholz, 2002). Yet, through the year 2000, less than 5\% of the total number of 2251 Presidential vetoes - just 114-targeted Indian matters. These few vetoes are the subject of a new Web presentation entitled I Forbid: Presidential Vetoes and American Indian Affairs, 1789-2000. The URL for this site is http://indianaffairsvetoes.unl.edu . The site has been cataloged (its OCLC accession number is 669481908) and is part of a collection of relevant materials ultimately pertaining to American Indian treaties. See http:/ / treatiesportal.unl.edu/ for the full suite.

Each relevant Indian affairs veto description found in Presidential Vetoes, 1789-1988 and in Presidential Vetoes, 1989-2000 is linked to its cited supporting documents, materials that may be found in the Congressional Record, in the Senate and House Journals, in the Statutes at Large, in the United States Congressional Serial Set, and even in Charles J. Kappler's Indian Affairs: Laws and Treaties; a few typographical errors in these descriptions were corrected during this processing. The supporting documents for each veto were purposely added to each summary because they frequently provided a useful historical path to the President's decision. These actions are ordered in two tables, one sorted by President and the other by entries from a cumulative index formed from the Presidential Vetoes series. Figure 1 provides the text of a typical veto recorded in the United States Congressional Serial Set, cast by William Howard Taft in 1912. It is identified as veto number 978 in the Web tables.

\section{Conclusions}

Felix S. Cohen pronounced that "[t]he purchase of more than two million square miles of land from the Indian tribes represents what is probably the largest real estate transaction in the history of the world" (Cohen, 1947, p. 42). The federal decision to conduct these negotiations through the formalization of treaty making which thereby made the results a part of the law of the land directly validated the sovereignty of the participating American Indian tribes. While not every subsequent Indian affairs veto noted here made direct reference to an entry in the Statutes at Large, the complex array of questions regarding railroad rights of way, or tribal actions before the Court of Claims, or educational or health care needs, or gathering rights arose because of the contents of those treaty documents. Whatever the final determination of each inquiry (only two of these specific vetoes were overridden by Congress), this collection of 114 brief political statements representing a small percentage of the total number of Presidential vetoes over the last two centuries offers one set of historical evidence that may assist an examination of the laws of this land and their impact on its indigenous peoples. It may simultaneously serve as a particularly clear window upon the evolution of Indian affairs in this country.

\section{References}

Bernholz, C. D., American Indian treaties and the Presidents: A guide to the treaties proclaimed by each administration. The Social Studies, 93 (2002), 218-227; http://digitalcommons.unl.edu/libraryscience/10/

Cohen, F. S., Original Indian title. Minnesota Law Review, 32 (1947), 28-59.

The Constitution of the United States: Analysis and Interpretation. Senate. 108th Congress, 2nd session. Senate Document No. 108 17 (Serial Set 14866). Washington, DC: Government Printing Office, 2004.

Mason, E. C., The Veto Power: Its Origin, Development and Function in the Government of the United States (1789-1889), 2nd ed. Boston, MA: Ginn \& Co, 1891.

Pope, J. H., The pocket veto reconsidered. Iowa Law Review, 72 (1986), 163214.

Presidential Vetoes,1789-1988, Senate Publication 102 12. Washington, DC: Government Printing Office, 1992.

Presidential Vetoes,1989-1991, Senate Publication 102 13. Washington, DC: Government Printing Office, 1992.

Presidential Vetoes,1989-1994, Senate Publication 103 13. Washington, DC: Government Printing Office, 1994.

Presidential Vetoes,1989-1996, Senate Publication 105 22. Washington, DC: Government Printing Office, 1997.

Presidential Vetoes,1989-2000, Senate Publication 107 10. Washington, DC: Government Printing Office, 2001.

Veto Messages of the Presidents of the United States, with the Action of Congress Thereon. Senate. 49th Congress, 2nd session. Senate Miscellaneous Document No. 53 (Serial Set 2451). Washington, DC: Government Printing Office, 1886.

Veto Message Relating to the Corbett Tunnel of the Shoshone Irrigation Project. Message from the President of the United States, returning without approval Senate Bill 4862 entitled An Act for the relief of certain persons having supplied labor and materials for the prosecution of the work of construction the Corbett Tunnel of the Shoshone Irrigation Project, together with the report of the Secretary of the Interior in relation thereto. Senate. 62nd Congress, 2nd session. Senate Document No. 878 (Serial Set 6182). Washington, DC: Government Printing Office, 1912. 